\title{
The Impact of a Funded Research Program on Music Education Policy
}

By: Donald A. Hodges and Mary Luehrsen

Hodges, D.A., \& Luehrsen, M. (2010). The impact of a funded research program on music education policy. Arts Education Policy Review, 111(2), 71-78.

DOI:10.1080/10632910903458854

This is an Accepted Manuscript of an article published by Taylor \& Francis in Arts Education Policy Review on August 8, 2010, available online: http://www.tandfonline.com/doi/10.1080/10632910903458854

\begin{abstract}
***(C) Taylor \& Francis Group, LLC. Reprinted with permission. No further reproduction is authorized without written permission from Taylor $\&$ Francis. This version of the document is not the version of record. Figures and/or pictures may be missing from this format of the document. $* * *$
\end{abstract}

\begin{abstract}
:
Sounds of Learning: The Impact of Music Education is a research program designed to allow researchers to examine the roles of music education in the lives of school-aged children to expand the understanding of music's role in a quality education. The NAMM Foundation, the sponsoring organization, has provided more than $\$ 1,000,000$ to fund research on the impact of music education on student achievement and success in school; all aspects of a child's growth and development; the uses and functions of music in daily life; and home, school, and community environments. Quality research about the role and impact of music education conducted by experienced researchers who publish in rigorous, peer-reviewed, scientific research journals plays a vital role in moving a public policy agenda forward to achieve expanded access to music education for all children. The goal is that this research will inform policy debates and development to achieve policies that support opportunities for every child to experience the power and benefits of learning music.

Keywords: music education | policy | research

\section{Article:}

Music educators have had to justify the role of music in the public school curriculum for the past 170 years. When Lowell Mason convinced the Boston School Board in 1837 to pay for a music teacher, he did so on the basis of music education's intellectual, moral, and physical merits (Birge 1966). Between that time and now, music educators have developed many different philosophical rationales for why music should be a basic part of every child's education. Furthermore, they have devised numerous advocacy positions to strengthen music's place in the schools. In difficult economic times, and when facing the pressures of standardized testing, school boards often seek to eliminate the costs of music instruction from the budget, and the resulting struggle of music programs to maintain a foothold in the curriculum has sometimes led to exaggerated claims about the power of music.
\end{abstract}


In addition to philosophical and advocacy statements, music educators have used research as a third weapon in their arsenal. Ironically, the first known American music education research study was conducted in 1837, the year of Mason's triumph, when Connecticut teachers were surveyed about the level of their musical skills (Mark 1992). Music education research began in earnest in 1953 with the publication of the Journal of Research in Music Education. Over the following fifty-six years, hundreds of articles in this and other journals have built a respectable body of literature.

Although research ought to play a more significant role in policy decisions (see, e.g., Hope 2002), it has often not. Some exaggerated claims for the importance of music education have been based on research from the fields of psychology and neuroscience that describes the benefits of music learning on cognitive tasks and extra-musical outcomes. Music education researchers have tended to not address the impact of music education relative to education policy developments or societal and advocacy issues that include equitable access to music education for all children. There are many reasons for a lack of research impact on policy, but important reasons have included a lack of sufficient and targeted funding, a lack of tradition, and a lack of opportunities in the field to pursue advanced study in education policy.

Table 1: Sounds of Learning Steering Committee

\begin{tabular}{ll}
\hline Member & \multicolumn{1}{c}{ Affiliation } \\
\hline $\begin{array}{l}\text { Pdward Asmus } \\
\text { Donald Hodges }\end{array}$ & $\begin{array}{l}\text { Professor of Music Education and Associate Dean, University of Miami, Frost School of Music } \\
\text { Professor of Music Education, University of Minnesota, School of Music } \\
\text { ivington Distinguished Professor of Music Education; Director, Music Research Institute, University of North Carolina at } \\
\text { Greensboro, School of Music }\end{array}$ \\
$\begin{array}{l}\text { Mary Luehrsen } \\
\text { Kristen Madsen }\end{array}$ & $\begin{array}{l}\text { Senior Vice President, The Grammy Foundation } \\
\text { Patricia Sink }\end{array}$ \\
Gavid Teachout & Graduate Advisor for Music Education, University of North Carolina at Greensboro, School of Music \\
\hline
\end{tabular}

Music education research has rarely been supported at a level that allows for the undertaking of major projects. Of course, by itself, funding is not a sufficient criterion to guarantee quality and high-impact research: what is needed is to harness a vision for policy-influencing research with sufficient resources to make a difference. Such a research program, entitled Sounds of Learning: The Impact of Music Education, has been underway for the past six years, and the purpose of this article is to provide information on it. A major goal of this program is, through sustained funding, to introduce a new tradition of inquiry and analysis to the music education research community, which would inspire a new generation of researchers seeking to contribute to a national and international dialogue about the impacts of music education and its relevance to larger societal concerns and issues. This article comprises three sections that present a brief overview and timeline of the program, details of two published studies, and the program's resulting influences on policymaking. Sounds of Learning presents the music education research community with opportunities to participate fully in policy dialogue and contribute to education policy in order to strengthen music education's role within a larger context. 


\section{A BRIEF OVERVIEW AND TIMELINE OF SOUNDS OF LEARNING}

In 2005, the National Association of Music Merchants (NAMM) Foundation (http://www.musicresearch.org/), a unit of NAMM: The International Music Products Association, initiated a major research program entitled Sounds of Learning: The Impact of Music Education (SoL). The NAMM Foundation sought to develop a stronger relationship with music education researchers based on a belief that the field's knowledge and interests were underrepresented in policy dialogues, and that there was the potential for music researchers to make important contributions to education policy debates about the impact of music education. There was also a need to restart a dialogue with music education researchers, many of who were skeptical of the motives of NAMM, the trade organization of the music products industry, in funding research. SoL is only one of many research programs supported by the NAMM Foundation, but it is the only one devoted to examining the role of music education in the lives of school-aged children and expanding the understanding of music's role in a quality education. A steering committee was established to guide SoL; the committee's members are listed in table 1. Subsequently, Debra O’Connell was hired as a Postdoctoral Fellow and added to the Committee.

The steering committee established an overarching goal for SoL of sponsoring research on four key issues: the impact of music education on student achievement and success in school; all aspects of a child's growth and development; the uses and functions of music in daily life; and home, school, and community environments. As a foundation for this research, the steering committee prepared a status report that provided a broad overview of the entire project (available online at http://www.uncg.edu/mus/soundsoflearning.html). This report establishes the context of the project, provides in-depth literature reviews, and lays out a research agenda to guide funded SoL research (see table 2).

Table 2: Table of Contents for Sounds of Learning Status Report

\begin{tabular}{lc}
\hline Chapter Title & Author(s) \\
\hline The Sounds of Learning Project & Hodges \\
The Impact of Music Education on Academic Achievement & Hodges and O'Connell \\
The Impact of Music Education on All Aspects of a Child's Growth and Development & Teachout \\
The Impact of Music Education on the Child's Self & O'Connell \\
The Uses and Functions of Music as a Curricular Foundation for Music Education & Haack \\
The Impact of Music Education on Home, School, and Community & Asmus \\
A Research Agenda to Investigate the Impact of Music Education & Hodges \\
\hline
\end{tabular}

An accompanying feature of the status report is a free, online database. Users can search for details of the 566 specific research studies included in the report. Each record includes complete citation information and an abstract, and is coded under one of five headings: achievement and success in school; home, school, and community; child's growth and development; uses and functions of music; and meta-analysis. Prior to posting the status report online, a review panel was established to provide feedback on the document. Table 3 presents members of this group, who were all recognized music education leaders, in their positions at the time. These members provided independent oversight, identified missing studies in the review chapters, made editorial suggestions to clarify broad understandings, and nominated items for the research agenda.

Beyond the organizational activities of preparing the status report and database, the primary focus of SoL has been to fund research that promotes the agenda. Accordingly, a series of 
Requests for Proposals (RFPs) has been advertised in six phases to date. Tables 4-9 list the titles of all advertised topics as a means of presenting the broad research agenda of SoL.

Table 3: Review Panel for Sounds of Learning Status Report

\begin{tabular}{|c|c|}
\hline Member & Affiliation \\
\hline David Circle & $\begin{array}{l}\text {;ident (2004-2006) of Music Educators National Conference: The National Association for Music Education; Coordinating } \\
\text { teacher for Blue Valley (KS) School District }\end{array}$ \\
\hline Charles Elliott & Director of the School of Music, University of Southern Mississippi \\
\hline Clifford Madsen & $\begin{array}{l}\text { Iert O. Lawton Distinguished Professor of Music, Coordinator of Music Education/Music Therapy/Contemporary Media, } \\
\text { Florida State University }\end{array}$ \\
\hline Gary McPherson & Zimmerman Professor of Music Education, University of Illinois \\
\hline Wendy Sims & Director of Studies in Music Education, University of Missouri; Editor, Journal of Research in Music Education \\
\hline Peter Webster & $\begin{array}{l}\text { John W. Beattie Professor of Music Education and Technology, Associate Dean for Academic Affairs and } \\
\text { Research, Northwestern University }\end{array}$ \\
\hline
\end{tabular}

\section{Phase 1}

To jumpstart research activities, the steering committee disseminated an RFP for short-term projects with an application deadline of April 15, 2005 (see table 4). Twelve proposals were submitted and two were selected for funding. Chris Johnson and Jenny Memmott, from the University of Kansas, received \$49,000 to conduct research entitled An Examination of the Impact of Participating in School Music Programs on Standardized Test Results. Pat Campbell, Claire Connell, and Amy Beegle, from the University of Washington, received \$39,190 for a study entitled The Importance of Music Education in the Lives of Teenagers. Both of these studies have been published, and the findings are discussed in a subsequent section.

Table 4: Phase 1 Request for Proposals (RFP)

\begin{tabular}{ll}
\hline RFP & Title \\
\hline$* 1.1$ & The Impact of Participating in School Music Programs on Standardized Test Results \\
$* 1.2$ & The Importance of Music Education in the Lives of Teenagers \\
1.3 & The Impact of a Quality Music Program on K-12 Education \\
\hline
\end{tabular}

*Two projects were funded in Phase 1 out of 12 sumbissions.

\section{Phase 2}

Although the studies conducted in Phase 1 were viewed as more short-term in nature, the steering committee also recognized that longterm projects were desirable. Therefore, later in 2005, they released another set of RFPs (see table 5). Sixteen proposals were submitted and four projects were funded.

Table 5: Phase 2 for Proposals (RFP)

\begin{tabular}{ll} 
RFP & \multicolumn{1}{c}{ Title } \\
\hline 2.1 & The Role of Music Education in Social Cohesion and Social Pluralism \\
2.2 & The Impact of Music Education on Adequate Yearly Progress as Defined by the No Child Left Behind Act \\
2.3 & The Impact of a Quality Music Program on K-12 Education \\
$* 2.4$ & Awareness of the Function of Music in Music Education \\
2.5 & The Role of Home Environment on Success in School Music and Student Success in School Music \\
$* 2.6$ & The Effects of Music Education on Self-Esteem/Self-Identity/Self-Image \\
$* 2.7$ & The Meanings of Music for Students in School-Based and Non-school Musical Activities \\
\hline
\end{tabular}


*Four projects were funded in Phase 2 out of 16 submissions.

The following are brief descriptions of the four accepted proposals:

- Alice-Ann Darrow, Florida State University. \$39,912. The Effect of Participation in a Music Mentorship Program on the Self Esteem and Attitudes of At-Risk Students and Students with Developmental Disabilities. The purpose of this study was to examine the effects of participation in a music mentorship program on the attitudes toward school and self-esteem of at-risk students and students with developmental disabilities.

- Gary McPherson, University of Illinois at Urbana-Champaign. \$95,348. Meanings of Music for Students in School-Based and Non-School Musical Activities. The purpose of this study was to examine the degree to which English and American students derive different meanings from their musical participation in school music education programs as compared to their participation in nonschool musical experiences.

- Dale Misenhelter, University of Arkansas, and Keith Kaiser, Ithaca College. \$4,000. Functions of Music in Music Education: A Curricular Look. The purpose of this study was to investigate the extent to which functions of music are evidenced and considered as part of curricula in school music programs.

- David Williams, University of South Florida. \$11,567. Musical Meaning: Teenage Participation in Musical Activities In and Out of School. The purpose of this study was to investigate the sociology of teenage musical involvement by using qualitative and quantitative methods to examine the types of meanings students derive from participation in school-based music education and nonschool musical experiences, as well as the sets of behaviors exhibited by these groups.

\section{Phase 3}

Phase 3 occurred during 2006. Eleven proposals were submitted and two were funded. Table 6 lists the RFPs for this phase.

Table 6: Phase 3 Request for Proposals (RFP)

\begin{tabular}{|c|c|}
\hline RFP & Title \\
\hline 3.1 & The Outcomes of an Effective K-12 Music Program \\
\hline 3.2 & Impact of Music Education on School Social Issues and Student Success \\
\hline *3.3 & Music Education and Adequate Yearly Progress as Defined by the No Child Left Behind Act \\
\hline *3.4 & $\begin{array}{l}\text { e Role of the Home Environment and Parent/Care Giver Attitudes on Student Success in Music and } \\
\text { School }\end{array}$ \\
\hline 3.5 & Impact of Learning Music/Outcomes of Music Instruction \\
\hline
\end{tabular}

Descriptions of the two funded projects are as follows:

- Martin Bergee, University of Missouri-Columbia. \$85,550. Music Education and Adequate Yearly Progress As Defined by the No Child Left Behind Act. The purpose of this 
project was to determine the relationship between music learning and reading and mathematics achievement as defined by the Adequate Yearly Progress measure of the No Child Left Behind Act of 2001. The project controlled for variables of grade level, gender, ethnicity, school location, music aptitude, parent/guardian levels of education, and socioeconomic level.

- Stephen F. Zdzinski, University of Miami. \$114,306. The Influence of Musical Home Environment, Family Background, and Parenting Style on Success in School Music and in School. The purpose of the study was to examine the role of various aspects of parental involvement, musical home environment, family background, and parenting style, and their influence on success in both school music and school. Secondary purposes were to examine the underlying structure of home environment in music and to develop a model of home environment in music education.

\section{Phase 4}

In 2007, ten proposals were submitted in response to the RFPs (see table 7). The three proposals funded in Phase 4 included:

- Harold Abeles, Teachers College, Columbia University. \$29,970. The Impact of Participation in an Established Music Program on the Academic Performance and Personal Development of At-Risk Elementary School Students. The purpose of this study was to explore the impact of participation in an established music program on the academic performance and personal development of at-risk elementary school students. An overarching goal was to determine the specific aspects of a music program experience that can leverage improved academic performance, so that this information can be used to sustain, enrich, and replicate quality music education programs, nationally and internationally, and in and out of school.

- Margaret Barrett, University of Tasmania; Jeffrey Bush, Margaret Schmidt, and Sandra Stauffer, Arizona State University. \$64,009. Impacts of an Effective Music Program: Outcomes and Values. The purpose of this project was to conduct a large-scale qualitative case study and program analysis based on designs consistent with qualitative organizational research and case study methods. The participants in this study were the stakeholders of the Mesa Public Schools in Mesa, Arizona, including students, music educators, classroom (K-6) and subject area (7-12) teachers, administrators, school board members, parents, businesspeople, community artists and musicians, community leaders, and nonparent citizens.

- Michael Raiber, University of Oklahoma. \$67,644. The Effects of Integrated Music Instruction on Academic Achievement among Students Involved in Arts-based School Reform. The purpose of this study was to examine the relationships between the level of music integration in nonmusic classes with student achievement in reading, math, social studies, science, and writing. A secondary purpose of the study was to examine the role of the music specialist within the integration process. 
Table 7: Phase 4 Request for Proposals (RFP)

\begin{tabular}{ll}
\hline RFP & \multicolumn{1}{c}{ Title } \\
\hline$* 4.1$ & The Outcomes of an Effective K-12 Music Program \\
4.2 & Impact of Music Education on School Social Issues and Student Success \\
4.3 & The Effect of Music Education on Creativity \\
$* 4.4$ & The Effect of Integrated Music Instruction on Teaching and Learning in Nonmusic Classes \\
4.5 & The Impact of Innovative Music Instructional Programs on Student Success in Music and in School \\
$* 4.6$ & Impact of Learning Music/Outcomes of Music Instruction \\
\hline
\end{tabular}

*Three studies were funded in Phase 4 out of 10 submissions.

\section{Phase 5}

In the spring of 2008, twelve proposals were submitted in response to the RFPs (see table 8).

Table 8: Phase 5 Request for Proposals (RFP)

\begin{tabular}{ll} 
RFP & \multicolumn{1}{c}{ Title } \\
$* 5.1$ & Economics of Music Education \\
$* 5.2$ & Characteristics of Communities that Strongly Support Music Education \\
5.3 & Rejuvenation of Urban Music Education \\
5.4 & The Impact of Sustaining and Eliminating Music Education Programs \\
5.5 & Impact of Learning Music/Outcomes of Music Instruction \\
\hline
\end{tabular}

*Two studies were funded in Phase 5 out of 12 submissions.

The following two projects were funded in Phase 5:

- $\quad$ Martin Bergee, Christopher Johnson, and Becky Eason, University of Kansas. \$87,746. Galvanizing Factors of Communities Chosen to Be One of the "Best 100 Communities for Music Education.” This study's purpose was to identify the galvanizing factors that distinguish communities that maintain and promote high-quality music programs from those communities that do not. The study had three phases. The first identified, via factor analysis, the factors latent in items comprising the "Best 100 Communities in Music Education" survey. The second phase consisted of (a) discriminant analysis using factor scores identified in the first phase as independent variables and group membership (i.e., selected or not selected as one of the 100 Best Communities) as the dependent variable; and (b) demographic analysis. The final phase was qualitative in nature and provided rich data on both the communities that were selected and those that were not. This phase consisted of ( $a$ ) the development of in-depth interview questions and $(b)$ face-to-face interviews with the persons who submitted their community's application, selected from a pool of communities chosen and not chosen.

- Paul Teske, School of Public Affairs, University of Colorado-Denver. \$126,069. Money for Music: The Real Costs and Benefits of K-12 Music Education. This proposal focused on the economics of music education in Jefferson County Public Schools, the largest school district in the state of Colorado. The study provided an in-depth analysis of the costs and benefits of a standards-based, sequential music education in the context of overall educational funding in the district. The study had three research questions:

o What are the total resources used for music education in the district and how do these resources vary by school? 
o What is the relationship between the amount of resources used for music education and the richness, diversity, alignment, and quality of the music programs at the school level?

o Is there a correlation between the amount of resources used at the school level and student learning outcomes (such as student assessment scores and graduation rates) and community support (such as school choices and participation in music events)?

\section{Phase 6}

In 2009, one project was funded out of the ten proposals submitted in response to the RFP (see table 9).

Table 9: Phase 6 Request for Proposals (RFP)

\begin{tabular}{cl}
$\mathbf{R F P}$ & \multicolumn{1}{c}{ Title } \\
\hline *6.1 & The Impact of Music Education on Creativity \\
6.2 & Experimental Study of Music Education Outcomes \\
6.3 & The Role of Music Education in Developing the Responsible Citizen \\
6.4 & Impact of Music Instruction \\
* One project was funded in Phase 6 out of 10 submissions.
\end{tabular}

The single funded proposal in Phase 6 was:

- Peter Webster, Northwestern University. \$102,282. Effects of Music Experiences During School Years on Professional Creative Achievement among a Sample of Architects, Chemical Engineers, and Music Educators. The purpose of this study was to investigate formal and informal musical experiences during elementary, secondary, and undergraduate college years for three select cohorts of professionals to determine whether these experiences were associated with creative achievement in the participants' respective fields. The three cohorts of professionals included a sampling of professional architects, chemical engineers, and music educators, all working in the Chicago area. A detailed, professionally developed questionnaire compared the experiences of a large sample of each cohort $(n=300)$ to a consensually identified creative subset from each cohort $(n=15$, labeled as the "creatives”) to determine possible statistically significant differences in the profiles of musical experiences. The researchers reasoned that if the profiles of experiences were significantly different for the creatives, this disparity might be a basis for believing in some association between music and creative achievement. In addition to the quantitative results from the questionnaire, the creatives were interviewed in depth to explore the results of the questionnaire and other factors drawn from the literature on adult creativity that might be self-identified as factors for their creative success.

Overall, SoL has funded fourteen proposals out of seventy-one submissions (table 10). Total expenditures on research projects alone have amounted to \$916,593. Three SoL meetings of the steering committee, review panel, funded researchers, and selected consultants have been convened to review and share progress. In total, the NAMM Foundation has spent well over a million dollars in supporting music education research. Details on the first two studies to appear in print, provided in the next section, give an indication of the richness of the resultant findings. 
Table 10: Summary of Six Phases of Sounds of Learning Requests for Proposals (RFP)

\begin{tabular}{|c|c|c|c|}
\hline RFP phase & $\begin{array}{c}\text { Ratio of projects } \\
\text { funded to } \\
\text { submissions }\end{array}$ & Projects funded & Amount (\$) \\
\hline \multirow[t]{2}{*}{1} & $2 / 12$ & $\begin{array}{l}\text { Johnson \& Memmott: Examination of the Impact of Participating in School Music } \\
\text { Programs } \\
\text { on Standardized Test Results }\end{array}$ & 49,000 \\
\hline & & $\begin{array}{l}\text { Campbell, Connell, \& Beegle: The Importance of Music Education in the Lives of } \\
\text { Teenagers }\end{array}$ & 39,190 \\
\hline \multirow[t]{4}{*}{2} & $4 / 16$ & Misenhelter \& Kaiser: Awareness of the Functions of Music in Music Education. & 4,000 \\
\hline & & $\begin{array}{l}\text { Darrow: What Kinds of Music Experiences Are Most Conducive to the Development } \\
\text { of a Positive Self-Esteem? }\end{array}$ & 39,912 \\
\hline & & $\begin{array}{l}\text { McPherson: Meanings of Music for Students in School-based and Non-school } \\
\text { Musical Activities }\end{array}$ & 95,348 \\
\hline & & Williams: Teenage Participation in Musical Activities In and Out of School. & 11,567 \\
\hline \multirow[t]{2}{*}{3} & $2 / 11$ & $\begin{array}{l}\text { Bergee: Music Education and Adequate Yearly Progress as Defined by the No } \\
\text { Child Left Behind Act }\end{array}$ & 85,550 \\
\hline & & $\begin{array}{l}\text { Zdzinski: The Influence of Musical Home Environment, Family Background, and } \\
\text { Parenting Style on Success in School Music and in School }\end{array}$ & 114,306 \\
\hline \multirow[t]{3}{*}{4} & $3 / 10$ & $\begin{array}{l}\text { Barrett, Bush, Schmidt, \& Stauffer: Impact of an Effective Music Program: Outcomes } \\
\text { and Values }\end{array}$ & 64,009 \\
\hline & & $\begin{array}{l}\text { Raiber: The Effects of Integrated Music Instruction on Academic Achievement } \\
\text { Among Students Involved in Arts-based School Reform }\end{array}$ & 67,644 \\
\hline & & $\begin{array}{l}\text { Abeles: The Impact of Participation in an Established Music Program on the } \\
\text { Academic Performance and Personal Development of At-Risk Elementary School } \\
\text { Students }\end{array}$ & 29,970 \\
\hline \multirow[t]{2}{*}{5} & $2 / 12$ & Teske: Money for Music: The Real Costs and Benefits of K-12 Music Education & 126,069 \\
\hline & & $\begin{array}{l}\text { Bergee, Johnson, \& Eason: Galvanizing Factors of Communities Chosen to be } \\
\text { One of the Best } 100 \text { Communities for Music Education }\end{array}$ & 87,746 \\
\hline 6 & $1 / 10$ & $\begin{array}{l}\text { Webster: Effects of Music Experiences During School Years on Professional Creative } \\
\text { Achievement Among a Sample of Architects, Chemical Engineers, and } \\
\text { Music Educators }\end{array}$ & 102,282 \\
\hline Totals & $14 / 71$ & & 916,593 \\
\hline
\end{tabular}

\section{DETAILS FROM TWO PUBLISHED STUDIES}

Sounds of Learning is fully committed to the peer-review process, and results of funded projects are not disseminated until they have appeared in print. To date, two funded SoL projects have been published. These are reviewed briefly here.

\section{Examination of Relationships between Participation in School Music Programs of Differing Quality and Standardized Test Results}

Johnson and Memmott (2006) sought to determine the relationships that exist between elementary and middle school students' performance on standardized tests and the quality of the music program (exemplary or deficient) at their schools. In the elementary school portion of the study, the test scores of 1,119 third and fourth graders were gathered from schools in southern, East Coast, midwestern, and West Coast regions of the United States that were identified by local university music education professors as having exemplary or deficient music programs. Because all children were attending general music classes, entire school populations could be compared. Students from midwestern, southern, and East schools with exemplary music programs scored significantly higher on both English and mathematics tests than their counterparts from schools with deficient music programs. West Coast students from schools with deficient music programs scored slightly higher on English tests and slightly lower on mathematics tests. Overall, students from schools with exemplary music programs scored 22 percent better on English standardized tests and 20 percent better on mathematics standardized tests. 
Because not all middle school students were enrolled in music classes, and because there were differences between instrumental and choral programs, data from 3,620 eighth and ninth grade students were grouped across the four geographical regions into categories of exemplary instrumental, exemplary choral, deficient instrumental, deficient choral, and no music. Students in exemplary instrumental and choral programs generally scored the highest. Students who received no music instruction and students in deficient choral programs scored the lowest in all four regions. Results for mathematics scores were similar, except that students from deficient instrumental programs outscored students from exemplary choral programs in two of the four regions.

The authors are careful to point out that this study examines relationships, not causation. In other words, there are no claims that being enrolled in music classes causes higher standardized test scores. However, they did find a positive relationship between quality of music instruction and performance on academic assessments. They attribute these findings to one of three likely sources: (a) schools that hire excellent music teachers are likely to hire excellent teachers in all subjects, (b) excellent music programs are likely to attract strong students, and (c) organizational skills and learning strategies learned in high quality music programs may transfer to other academic areas.

\section{Adolescents' Expressed Meanings of Music In and Out of School}

Campbell, Connell, and Beegle (2007) examined written comments from 1,155 American middle and high school students, aged 13-18, who submitted essays to a contest called "Ban the Elimination of Music in the Schools”. Respondents were overwhelmingly female (78 percent), and nearly two-thirds were between 14 and 16 years of age. The researchers conducted a content analysis of the essays, and results were reported under the following headings:

- Adolescent-identified musical involvement. Although nearly all the students hinted that they had music learning experiences, about one-third specifically mentioned having taken lessons or been in a musical group. Responses were nearly evenly divided between popular instruments (e.g., guitar) and band or orchestra instruments. A few students identified themselves as singers or composers.

- Music-specific benefits. Students reported that they had learned specific musical skills such as note-reading, performance, listening, and personal-expressive skills. Students particularly recognized the importance of music education classes in the development of performance skills. Interestingly, students also acknowledged the role of music instruction in learning about other cultures, histories, and societies.

- Emotional benefits. The powerful role that music plays in the emotional lives of teenagers was expressed repeatedly in these essays. Students wrote about how music enabled them to express and release both positive and negative emotions. They saw music as a means of coping with the daily stresses of school, family, and relationships.

- Life benefits. Adolescents felt that music study has benefits that transfer into other areas of life. They wrote that the concentration and hard work necessary for success in music 
develops self-discipline and impacts success both in and out of school. Music was also seen to be a positive influence on such aspects of character as confidence, responsibility, compassion, pride, patience, and respect.

- Social benefits. Students wrote about meeting people and making new friends through music. Participation in music was a way to belong, and students often invoked the imagery of family. They also felt that participating in music helped distract them from the lure of inappropriate behaviors involving alcohol, cigarettes, drugs, gangs, and promiscuous sex. Many also referred to the role music played in helping teens avoid depression and suicidal thoughts.

- Music curriculum, courses, and teachers. Many of the essayists wrote passionately about the importance of music in the school curriculum. They often placed music on par with traditional academic subjects (e.g., math). They felt that the informational content was valuable, in addition to the emotional benefits. Overall, students expressed a strong desire to maintain or increase the presence of music in the school curriculum. Finally, they acknowledged the important contributions that music teachers have made to their lives.

The remaining SoL-funded projects are in press, under review, recently submitted, or in progress. As they are published, they will add to the base of knowledge established by the studies already in print. Collectively, these and future projects have the potential to make substantive contributions to policy discussions concerning the place of music education in the public school curriculum. The current status of that discussion is explored in the next section.

\section{POLICY IMPLICATIONS OF SOUNDS OF LEARNING RESEARCH}

In February 2007, NAMM hosted SoL researchers Chris Johnson, Patricia Campbell, and Gary McPherson to present testimony about their research outcomes to education committees in the U.S. House of Representatives and the Senate. Lead education legislative staff members attended the presentations and discussions about the context and content of the outcomes presented by these researchers. This occasion was the first time that federal education policymakers had heard about specific impacts and outcomes of music education directly from music education researchers. It is difficult to measure how these presentations have directly correlated to specific policy or legislative developments, given the prolonged nature of legislative undertakings. However, the presentations were pivotal to NAMM's efforts to develop legislative champions for music education in Congress within the context of reauthorization of the nation's education act, and to advance a dialogue about potential changes within the Elementary and Secondary Education Act, renamed No Child Left Behind in 2001. Since these meetings, NAMM and its advocacy partners, including MENC, have worked with members of Congress to propose and review precise language that designates music education as a core curriculum subject and allows greater flexibility within programs under the federal education funding act for states and local school districts to use funds for nontested core subjects including music education.

As indicated, several SoL proposals are in the pipeline for publication and presentation at conferences and hold promise for advancing a dialogue with the federal, state, and local policy and education leaders who determine education funding and priorities for education, including 
music education. Studies include:

- the effects of music education on self-esteem and the meanings of music for students (phase 2);

- music education, adequate yearly progress, and the role of the home environment (phase 3);

- the impact, outcomes, and values of an effective music program and arts-integrated instruction, and their effects on at-risk elementary students (phase 4);

- the costs and economic benefits of music education and the characteristics of communities that strongly support music education (phase 5);

- and the role that music learning has on developing creativity (phase 6).

These kinds of studies break new ground that is relevant to public policy development that advances access to music education.

Quality research about the role and impact of music education conducted by experienced researchers who publish in rigorous, peer-reviewed, scientific research journals plays a vital role in moving a public policy agenda forward to achieve expanded access to music education for all children. As policymakers on federal, state and local levels consider educational priorities and set guidelines, they must seek out and review research to inform decision making. Research staff working for legislators and policy organizations often request research summaries outlining the impact and benefits of music education and its contribution to larger societal needs, including its impact on student learning and achievement. Advocacy activities often draw material from the neuroscience and cognitive psychology fields. Although this research has contributed to policy dialogues, it does not always express the full richness of sequential learning in music education, which is the purview of researchers grounded in music education practice and theory. We hope that the continuing development of the music education research field will yield more policyrelevant research in years to come, and that this research will inform policy debates and development to achieve policies that support opportunities for every child to experience the power and benefits of learning music.

\section{REFERENCES}

Birge, E. 1966. History of public school music in the United States, Washington, DC: Music Educators National Conference.

Campbell, P., Connell, C. and Beegle, A. 2007. Adolescents' expressed meanings of music in and out of school. Journal of Research in Music Education, 55(3): 220-36.

Hope, S. 2002. "Policy frameworks, research, and K-12 schooling”. In The new handbook of research on music teaching and learning, Edited by: Colwell, R. and Richardson, C. 516. New York: Oxford University Press. 
Johnson, C. and Memmott, J. 2006. Examination of relationships between participation in school music programs of differing quality and standardized test results. Journal of Research in Music Education, 54(4): 293-307.

Mark, M. 1992. “A history of music education research”. In Handbook of research on music teaching and learning, Edited by: Colwell, R. 48-59. New York: Schirmer. 